\title{
Microhardness assessment of different commercial brands of resin composites with different degrees of translucence
}

Taciana Emília de Almeida Anfe (a) Taciana Marco Ferraz Caneppele ${ }^{(b)}$ Carlos Martins Agra ${ }^{(c)}$

Glauco Fioranelli Vieira ${ }^{(d)}$

(a) Graduate Student, School of Dentistry, University of São Paulo, São Paulo, SP, Brazil.

(b) Graduate Student, School of Dentistry of São José dos Campos, São Paulo State University, São José dos Campos, SP, Brazil.

(c) $\mathrm{PhD}$ in Restorative Dentistry; ${ }^{(d)}$ Associate Professor - Department of Restorative Dentistry, School of Dentistry, University of São Paulo, São Paulo, SP, Brazil.

\begin{abstract}
Owing to improvements in its mechanical properties and to the availability of shade and translucence resources, resin composite has become one of the most widely used restorative materials in present day Dentistry. The aim of this study was to assess the relation between the surface hardness of seven different commercial brands of resin composites (Charisma, Fill Magic, Master Fill, Natural Look, Opallis, Tetric Ceram, and Z250) and the different degrees of translucence (translucid, enamel and dentin). Vickers microhardness testing revealed significant differences among the groups. Z250 was the commercial brand that showed the best performance in the hardness test. When comparing the three groups assessed within the same brand, only Master Fill and Fill Magic presented statistically significant differences among all of the different translucencies. Natural Look was the only one that showed no significant difference among any of the three groups. Charisma, Opallis, Tetric Ceram and Z250 showed significant differences among some of the tested groups. Based on the results found in this study, it was not possible to establish a relation between translucence and the microhardness of the resin composites assessed. Depending on the material assessed, however, translucence variation did affect the microhardness values of the resin composites.
\end{abstract}

Descriptors: Composite resins; Hardness; Color.

\section{Corresponding author:}

Taciana Emília de Almeida Anfe

Av. Dr. Octávio da Silva Bastos, 4035

São João da Boa Vista - SP - Brazil

CEP: 13874-651

E-mail: tacianfe@uol.com.br

Received for publication on May 03, 2007

Accepted for publication on Oct 08, 2007 


\section{Introduction}

Resin composite is one of the restorative materials most widely used in present day Dentistry. This is mainly due to three factors: the first one is adhesion to tooth structure, the second is the improvement in its mechanical properties and the third reason is the availability of shades and translucence options that provide almost unlimited possibilities for this material to imitate the tooth.

Among the most studied mechanical properties are flexural resistance and hardness, because they approximate the forces involved in mastication and those supported by the material. Various authors have shown that these are related to the characteristics of the organic matrix, the percentage volume and the type of load.

Tooth shade is given by the color and translucence of the tooth enamel and the color of dentin. With the purpose of increasingly imitating the dental pat- tern, highly translucent resins have been launched, and these are used in the incisal third of an anterior restoration, or to cover the last layer of a posterior reconstruction, which results in the material receiving intense masticatory load. It is not stated in the literature whether, within one and the same commercial brand, translucent resin supports the same load as does resin for enamel and for dentin.

The authors were interested in finding out whether a resin composite of the same commercial brand is altered by the use of translucent composite for finishing the restoration. The aim of this study was to assess the relation between the surface hardness of seven different commercial brands of resin composites with different degrees of translucence.

\section{Material and Methods}

Seven different commercial brands of resin composites were tested. Of each brand, 3 shades were

Chart 1 - Selected Microhybrid Resins.

\begin{tabular}{|c|c|c|c|c|c|c|}
\hline Resin Composites & Organic Matrix & Inorganic Load & $\begin{array}{l}\text { Volume } \\
\text { of Load }\end{array}$ & $\begin{array}{l}\text { Weight of } \\
\text { Load }\end{array}$ & Shade & Batch n. \\
\hline $\begin{array}{l}\text { Charisma } \\
\text { Heraeus-Kulzer } \\
\text { (Wehrheim, } \\
\text { Germany) }\end{array}$ & $\begin{array}{l}\text { - BisGMA } \\
\text { - TEGDMA }\end{array}$ & $\begin{array}{l}\text { - barium aluminum } \\
\text { fluoride glass } \\
\text { - high/dispersed silicon } \\
\text { dioxide }\end{array}$ & $61 \%$ & $78 \%$ & $\begin{array}{l}\text { Incisal } \\
\text { B2 } \\
\text { OB2 }\end{array}$ & $\begin{array}{l}010039 \\
010200 \\
010202\end{array}$ \\
\hline $\begin{array}{l}\text { Fill Magic } \\
\text { Vigodent } \\
\text { (Rio de Janeiro, } \\
\text { RJ, Brazil) }\end{array}$ & - methacrylate monomers & $\begin{array}{l}\text { - pryogenic silicon } \\
\text { - barium and aluminum } \\
\text { silicate }\end{array}$ & - & $80 \%$ & $\begin{array}{l}\text { Incisal } \\
\text { B2 enamel } \\
\text { B2 dentin }\end{array}$ & $\begin{array}{l}223 / 05 \\
067 / 06 \\
035 / 06\end{array}$ \\
\hline $\begin{array}{l}\text { Master Fill } \\
\text { Biodinâmica } \\
\text { (Ibiporã, PR, Brazil) }\end{array}$ & $\begin{array}{l}\text { - bisphenol A glycidyl methacrylate } \\
\text { - ethylene urethane dimethacrylate }\end{array}$ & $\begin{array}{l}\text { - titanium dioxide } \\
\text { - iron oxide }\end{array}$ & - & $79 \%$ & $\begin{array}{l}\text { Incisal } \\
\text { B2 } \\
\text { OB2 }\end{array}$ & $\begin{array}{c}953 / 04 \\
022 / 06 \\
1050 / 05\end{array}$ \\
\hline $\begin{array}{l}\text { Natural Look } \\
\text { DFL } \\
\text { (Rio de Janeiro, RJ, } \\
\text { Brazil) }\end{array}$ & $\begin{array}{l}\text { - bisphenol A diglycidyl methacrylate } \\
\text { - bisphenol A diethoxy methacrylate } \\
\text { - triethylene glycol dimethacrylate }\end{array}$ & $\begin{array}{l}\text { - silanized barium } \\
\text { crystals } \\
\text { - hydrophobic } \\
\text { amorphous silica }\end{array}$ & $58.5-59 \%$ & $77-78 \%$ & $\begin{array}{l}\text { Incisal } \\
\text { B2 enamel } \\
\text { B2 dentin }\end{array}$ & $\begin{array}{l}06010169 \\
06010141 \\
06030531\end{array}$ \\
\hline $\begin{array}{l}\text { Opallis } \\
\text { FGM } \\
\text { (Joinville, SC, Brazil) }\end{array}$ & $\begin{array}{l}\text { - } \text { BisGMA } \\
\text { - BisEMA } \\
\text { - } \text { TEGDMA }\end{array}$ & $\begin{array}{l}\text { - barium glass } \\
\text { - aluminum silicate } \\
\text { - silica dioxide }\end{array}$ & $57-58 \%$ & $77.5-79 \%$ & $\begin{array}{l}\text { T-yellow } \\
\text { EB2 } \\
\text { DB2 }\end{array}$ & $\begin{array}{l}\text { 03APR06 } \\
\text { 19JUL06 } \\
\text { 24MAY06 }\end{array}$ \\
\hline $\begin{array}{l}\text { Tetric } \\
\text { Ceram } \\
\text { Ivoclar Vivadent } \\
\text { (Schaan, } \\
\text { Liechtenstein) }\end{array}$ & $\begin{array}{l}\text { - } \text { BisGMA } \\
\text { - urethane dimethacrylate } \\
\text { - triethylene glycol dimethacrylate }\end{array}$ & $\begin{array}{l}\text { - barium glass } \\
\text { - aluminum and barium } \\
\text { fluorosilicate glass } \\
\text { - high/dispersed silicon } \\
\text { dioxide } \\
\text { - mutual spheroid oxides }\end{array}$ & $60 \%$ & $79 \%$ & $\begin{array}{l}\text { T } \\
\text { B2 enamel } \\
\text { B2 dentin }\end{array}$ & $\begin{array}{l}\text { H36386 } \\
\text { H34662 } \\
\text { H30145 }\end{array}$ \\
\hline $\begin{array}{l}\text { Z250 } \\
\text { 3M ESPE } \\
\text { (St. Paul, MN, USA) }\end{array}$ & $\begin{array}{l}\text { - } \text { BisGMA } \\
\text { - } \text { UDMA } \\
\text { - } \text { BisEMA }\end{array}$ & $\begin{array}{l}\text { - zirconia } \\
\text { - Silicon }\end{array}$ & $60 \%$ & $82 \%$ & $\begin{array}{l}\text { Incisal } \\
\text { B2 } \\
\text { UD }\end{array}$ & $\begin{array}{l}\text { 6LU } \\
6 \mathrm{WG} \\
6 \mathrm{AP}\end{array}$ \\
\hline
\end{tabular}


selected (translucent, enamel B2 and dentin B2), making a total of 21 groups of resin samples with 5 test specimens for each group (Chart 1 ).

For each of the selected resin composite samples, surface microhardness was assessed.

\section{Surface hardness test}

A Teflon matrix $5 \mathrm{~mm}$ in diameter and $2 \mathrm{~mm}$ in thickness was used to make the test specimens. A glass slide (used in optic microscopy) was placed on a flat surface, and on top of it, a polyester strip. The Teflon matrix was placed on the polyester strip and filled with resin composite, and on top of that, another polyester strip and another glass slide were set. Digital pressure on the glass slide guaranteed that a smooth flat surface was obtained. The resin composite was light activated in the center of the sample for 40 seconds on each of its two surfaces through the glass slide (JetLite 4000 Plus, J. Morita USA Inc., Mason Irvine, CA, USA). Five specimens were made of each material. The specimens were then stored in distilled water at $37^{\circ} \mathrm{C}$ for 7 days.

Microhardness measurements on each specimen were made with a Vickers tester (HMV 2000, Shimadzu, Kyoto, Japan) with a load of $50 \mathrm{~g}$ for $45 \mathrm{~s}$, using an objective of $50 \mathrm{X}$. On every test specimen, 5 measurements were made, avoiding the peripheral areas of the sample.

Statistical analysis of the data obtained was performed. The non-parametric Kruskal-Wallis test (significance of $5 \%$ ) was selected for the analysis because the values did not meet the normality and homogeneity requirements. The test revealed significant differences among the groups. The Mann-Whitney test (significance of $5 \%$ ) was applied to determine which groups differed among them. The second step of the statistical analysis assessed whether there were differences among the 7 brands of resins. Grouping of the values revealed that they filled the homogeneity and normality requirements, which enabled the ANOVA statistical test to be applied with a significance of $5 \%$. The Scheffe test (significance of $5 \%$ ) determined the differences among the groups.

\section{Results}

The 21 groups of samples were assessed to ver- ify whether there were significant differences. The Mann-Whitney test (significance of 5\%) was applied to determine which groups differed among them. The consolidated results are shown in Table 1.

In Table 1, it is possible to observe that, within the same commercial brand, only the Master Fill and Fill Magic presented statistically significant differences among the three groups tested (shades: translucent, enamel B2 and dentin B2). Natural Look was the only one that showed no significant differences among any of the groups. Charisma, Opallis, Tetric Ceram and Z250 showed significant differences among some of the tested groups. Comparisons were also made among all the commercial brands assessed. However, there was no homogeneity among the results found. Thus, the translucent

Table 1 - Comparison of hardness values among groups considering the results obtained with the Mann-Whitney test.

\begin{tabular}{l|c|c}
\hline \multicolumn{1}{c|}{ Resins } & Mean (VHN) & \\
\hline Charisma I & 68.49 & $(\mathrm{~A})$ \\
\hline Charisma B2 & 61.57 & $(\mathrm{~B})$ \\
\hline Charisma OB2 & 65.13 & $(\mathrm{~A}, \mathrm{~B}, \mathrm{C})$ \\
\hline Fill Magic I & 54.76 & $(\mathrm{D})$ \\
\hline Fill Magic B2E & 64.02 & $(\mathrm{~A}, \mathrm{~B}, \mathrm{C}, \mathrm{E})$ \\
\hline Fill Magic B2D & 67.32 & $(\mathrm{~A}, \mathrm{C}, \mathrm{F})$ \\
\hline Master Fill I & 47.76 & $(\mathrm{P})$ \\
\hline Master Fill B2 & 51.75 & $(\mathrm{G})$ \\
\hline Master Fill OB2 & 55.72 & $(\mathrm{D}, \mathrm{H})$ \\
\hline Natural Look I & 64.16 & $(\mathrm{~A}, \mathrm{~B}, \mathrm{C}, \mathrm{F}, \mathrm{I})$ \\
\hline Natural Look B2E & 64.37 & $(\mathrm{~A}, \mathrm{~B}, \mathrm{C}, \mathrm{E}, \mathrm{I}, \mathrm{J})$ \\
\hline Natural Look B2D & 65.76 & $(\mathrm{~A}, \mathrm{C}, \mathrm{E}, \mathrm{F}, \mathrm{I}, \mathrm{J}, \mathrm{K})$ \\
\hline Opallis T-Y & 57.76 & $(\mathrm{D}, \mathrm{H}, \mathrm{L})$ \\
\hline Opallis EB2 & 62.52 & $(\mathrm{~B}, \mathrm{C}, \mathrm{E}, \mathrm{I}, \mathrm{J}, \mathrm{K}, \mathrm{M})$ \\
\hline Opallis DB2 & 62.22 & $(\mathrm{~B}, \mathrm{E}, \mathrm{I}, \mathrm{M})$ \\
\hline Tetric Ceram T & 57.4 & $(\mathrm{D}, \mathrm{H}, \mathrm{L}, \mathrm{N})$ \\
\hline Tetric Ceram B2E & 57.91 & $(\mathrm{~L}, \mathrm{~N})$ \\
\hline Tetric Ceram B2D & 50.59 & $(\mathrm{G})$ \\
\hline Z250 I & 96.39 & $(\mathrm{O}, \mathrm{Q})$ \\
\hline Z250 B2 & 94.06 & $(\mathrm{O})$ \\
\hline Z250 UD & 96.38 & \\
\hline Rerin & & \\
\hline
\end{tabular}

Resin composites that did not present statistically significant differences are listed above with the same letter in brackets. 


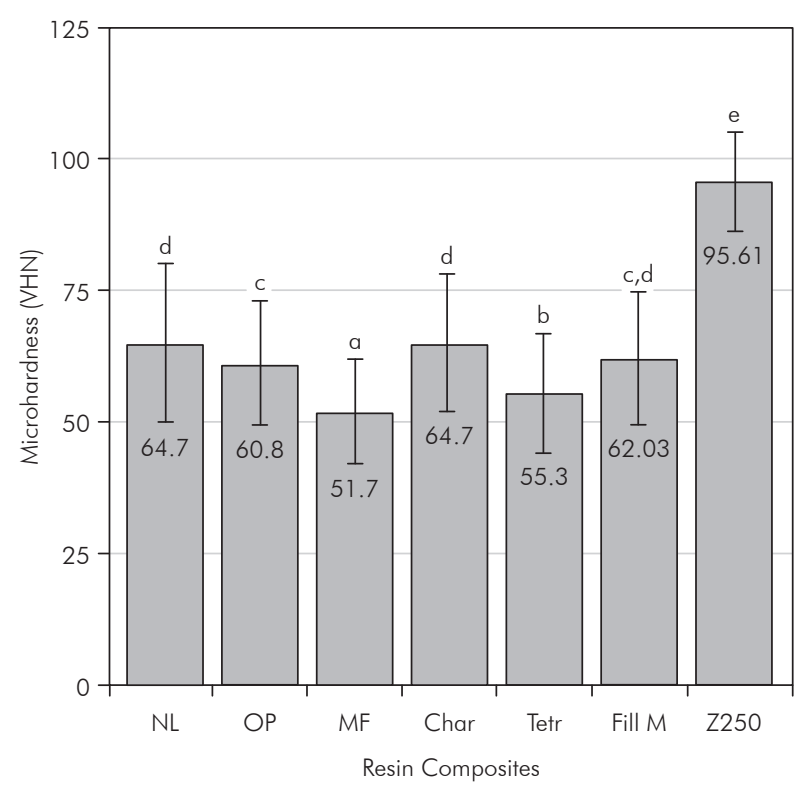

Graph 1 - Comparison of hardness values obtained for the different brands assessed. (Resin composites that did not present statistically significant differences are presented above with the same letter.)

resin presented higher or lower hardness values, depending on the commercial brand in question.

The second step of the statistical analysis assessed whether there were differences among the 7 brands of resins. Grouping of the values revealed that they filled the homogeneity and normality requirements, which enabled the ANOVA statistical test to be applied with a significance of $5 \%$. The Scheffe test (significance of $5 \%$ ) determined the differences among the groups. Graph 1 shows the values obtained in the hardness test for the resin composites assessed.

\section{Discussion}

The mechanical properties of a resin composite, considering the material's composition, are related to the polymeric matrix, the inorganic load and the bonding agent. The surface hardness of a composite is determined both by the matrix and the inorganic load, so it is important to assess the properties of these components.

The factor addressed in this research was the relation between translucence and surface microhardness of resin composites. With an increasing demand for esthetics, by both professionals and pa- tients, companies have developed resin composites with options not only of shades, but with a large variation in translucence, in an endeavor to obtain more and more natural results. Nevertheless, professionals are concerned about whether this variation in translucence affects the mechanical properties of the material. It is known that the shade of a resin and the particle size of its load may affect both translucence and the dispersion of light, and consequently the polymerization depth of the composite, ${ }^{1}$ which may alter its hardness.

Translucence, even more so than color, may be a limiting factor with regard to the polymerization depth of some resinous systems. ${ }^{1,2}$ Resins with a similar composition may present different hardness values due to their characteristics of being more or less translucent. ${ }^{3} \mathrm{~A}$ more translucent material allows better light transmission from the light polymerizer, which results in a higher degree of conversion and consequently higher hardness. ${ }^{4,5}$ The difference of hardness between bottom and top surfaces is smaller in the more translucent resin composites than in the less translucent materials. ${ }^{3,6}$ Light transmission through darker colors is diminished because of less translucence. $^{7}$

In agreement with the data presented by Aguiar et al. ${ }^{7}$ (2005), in the present study, the observed surface microhardness values did not vary significantly as a function of the degree of translucence of the composites. Nevertheless, although there was no homogeneity in the results found, there were statistically significant differences in the surface microhardness results of some of the commercial brands when translucence was a variable. For the composites Charisma, Opallis, Tetric Ceram and Z250, significant differences were observed among some of the resins with different degrees of translucence within the same commercial brand. The composites Master Fill and Fill Magic presented significant differences among all the different translucencies assessed. Whereas the Natural Look resin was the only one that showed no significant differences among any of the different degrees of translucence (Table 1).

The differences observed in the microhardness test results presented by composites of the same 
commercial brand could be explained by an alteration in composition. The component responsible for the degree of resin translucence is the factor that would have an influence on this result. However, the authors do not know what really differs among the translucent resins for enamel and dentin. The majority of manufacturers allege that what is altered is the quantity of inorganic load. But, in the present study, it was not possible to establish a direct parallel between the percentage of inorganic load and surface hardness. Thus, it is probable that the organic component of the resins plays a decisive role in this property.

Many authors allege that the degree of translucence of a resin composite may interfere in adequate polymerization of the material. ${ }^{1,6,8}$ Nevertheless, according to the data found in the present research, whether or not a resin composite is translucent is not a determining factor in the surface hardness result. If this were so, translucent composites would present better results in the microhardness test. But in the present study, only the Charisma presented a higher hardness value for the incisal shade, in comparison with the resin samples within the same commercial brand. Among the other commercial brands, the incisal shade sample presented a lower (Fill Magic, Master Fill, Natural Look, Opallis) or intermediate (Tetric Ceram and Z250) hardness value when compared to the enamel and dentin shades. Thus, the supposition that translucence would be a determinant factor in a resin composite's microhardness was not confirmed.

In the present study, the test specimens assessed were $2 \mathrm{~mm}$ in thickness. Although some authors ${ }^{1,2}$ have demonstrated that the hardness assessed at depth underwent alteration as a result of shade or translucence, Martins et al. ${ }^{9}$ (2002) and Santos et al. ${ }^{10}$ (2000) related that there was no difference in microhardness in the first $2 \mathrm{~mm}$ of resin composite depth as a result of change in shade. That is why the authors decided to assess surface hardness only. Moreover, in a resin composite restoration using the direct technique, the recommendation for attaining adequate polymerization is to work with increments of up to $2 \mathrm{~mm}$. It is important to note that, in this study, the composite was cured through the polyes- ter strip and received no further surface treatment. Some studies ${ }^{11,12}$ relate that there is a resin-rich surface layer when the polymerization occurs through a polyester strip and it would result in a lower surface hardness. However, Park et al. ${ }^{13}$ (2000) related that after 6 days of the polymerization there is no difference between polished and polyester strip-finished surfaces in Vickers microhardness.

A resin composite's hardness depends on how the organic matrix is formed, ${ }^{14}$ and on its density and structure. The polymeric matrix is formed through the conversion of the double carbon bonds of monomers into covalent links, forming polymeric chains. The degree of conversion of a resin composite depends on the type of monomer and the quantity of photoinitiators present, and has a direct influence on hardness. A greater degree of conversion is commonly associated with a greater degree of hardness. ${ }^{15}$ Some researchers have related that the hardness test can be used as an indirect method for assessing the degree of conversion of resin composites: the greater the degree of conversion, the greater the hardness. ${ }^{16,17}$ Nevertheless, hardness values cannot be used to compare the degree of conversion among different composites, since the results depend largely on the composition of the material. ${ }^{8}$ The type of polymeric chain that is formed after polymerization affects hardness. The mechanical properties are dependent on the formation of crossed chains, which does not necessarily indicate the degree of conversion of a resin. ${ }^{18}$

Different monomers present particular characteristics and different properties. It is known that there are variations among monomers as regards hydrophilia, degree of conversion and capacity to form crossed chains during polymerization. Among the composites assessed there was little variation in the organic matrix composition. The exception was Z250 that had no TEGDMA in its composition. TEGDMA is a low-molecular-weight monomer, whereas UDMA and BisEMA have higher molecular weights. All of them are dilutant monomers of BisGMA, present in all the resins assessed.

Some authors affirmed that the quantity of load is directly related to surface hardness. ${ }^{16,17,19,20}$ The greater the percentage volume of the load, the high- 
er the hardness. ${ }^{21}$ Nevertheless, in the present study the data found are contrary to this evidence and are in agreement with the results found by Mandikos et al. ${ }^{14}$ (2001). The greater hardness of Z250 cannot be explained by the high percentage volume of the load in this material. Charisma presents a higher percentage volume $(61 \%)$ and Tetric Ceram has a value equal to that of Z250 (60\%). However, the hardness values presented by these two resin composites were significantly lower than those of resin Z250.

The materials assessed differ both in their organ-

\section{References}

1. Ferracane JL, Aday P, Matsumoto H, Marker VA. Relationship between shade and depth of cure for light-activated dental composite resins. Dent Mater. 1986;2(2):80-4.

2. Shortall AC. How light source and product shade influence cure depth for a contemporary composite. J Oral Rehabil. 2005;32(12):906-11.

3. Kawaguchi M, Fukushima T, Miyazaki K. The relationship between cure depth and transmission coefficient of visible-lightactivated resin composites. J Dent Res. 1994;73(2):516-21.

4. Bouschlicher MR, Rueggeberg FA, Wilson BM. Correlation of bottom-to-top surface microhardness and conversion ratios for a variety of resin composite compositions. Oper Dent. 2004;29(6):698-704.

5. Leloup G, Holvoet PE, Bebelman S, Devaux J. Raman scattering determination of the depth of cure of light-activated composites: influence of different clinically relevant parameters. J Oral Rehabil. 2002;29(6):510-5.

6. Shortall AC, Wilson HJ, Harrington E. Depth of cure of radiation-activated composite restoratives - influence of shade and opacity. J Oral Rehabil. 1995;22(5):337-42.

7. Aguiar FHB, Lazzari CR, Lima DBNL, Ambrosano GMB, Lovadino JR. Effect of light curing tip distance and resin shade on microhardness of a hybrid resin composite. Braz Oral Res. 2005;19(4):302-6.

8. César PF, Miranda Júnior WG, Braga RR. Influence of shade and storage time on flexural strength, flexural modulus, and hardness of composites used for indirect restorations. J Prosthet Dent. 2001;86(3):289-96.

9. Martins F, Delbem ACB, Santos LRA, Soares HLO, Martins EOB. Microdureza de resinas em função da cor e luz halógena. Pesqui Odontol Bras. 2002;16(3):246-50.

10. Santos LA, Turbino ML, Youssef MN, Matson E. Microdureza de resina composta: efeito de aparelhos e tempos de polimerização em diferentes profundidades. Pesqui Odontol Bras. 2000;14(1):65-70.

11. Gordan VV, Patel SB, Barrett AA, Shen C. Effect of surface finishing and storage media on bi-axial flexure strength ic and inorganic compositions, which makes it difficult to compare the results among the tested commercial brands. ${ }^{15,17,20,22}$

\section{Conclusion}

Based on the data found in the present study, it was not possible to establish a relation between translucence and the microhardness values of the resin composites assessed. Depending on the material assessed, however, translucence variation did affect the microhardness values of the resin composites.

and microhardness of resin-based composite. Oper Dent. 2003;28(5):560-7.

12. Yap AUJ, Lye KW, Sau CW. Surface characteristics of toothcolored restoratives polished utilizing different polishing systems. Oper Dent. 1997;22(6):260-5.

13. Park SH, Krejci I, Lutz F. Hardness of celluloid strip-finished or polished composite surfaces with time. J Prosthet Dent. 2000;83(6):660-3.

14. Mandikos MN, McGivney GP, Davis E, Bush PJ, Carter JM. A comparison of the wear resistance and hardness of indirect composite resins. J Prosthet Dent. 2001;85(4):386-95.

15. Manhart J, Kunzelmann KH, Chen HY, Hickel R. Mechanical properties of new composite restorative materials. J Biomed Mater Res. 2000;53(4):353-61.

16. Kwon YH, Jeon GH, Jang CM, Seol HJ, Dim HI. Evaluation of polymerization of light-curing hybrid composite resins. J Biomed Mater Res Part B Appl Biomater. 2006;76(1):10613.

17. Pereira SG, Osório R, Toledano M, Nunes TG. Evaluation of two Bis-GMA analogues as potential monomer diluents to improve the mechanical properties of light-cured composite resins. Dent Mater. 2005;21(9):823-30.

18. Ferracane JL. Correlation between hardness and degree of conversion during the setting reaction of unfilled dental restorative resins. Dent Mater. 1985;1(1):11-4.

19. Kim KH, Ong JL, Okuno O. The effect of filler loading and morphology on the mechanical properties of contemporary composites. J Prosthet Dent. 2002;87(6):642-9.

20. Neves AD, Discacciati JAC, Oréfice RL, Jansen WC. Correlação entre grau de conversão, microdureza e conteúdo inorgânico em compósitos. Pesqui Odontol Bras. 2002;16(4):349-54.

21. Knobloch LA, Kerby RE, Clelland N, Lee J. Hardness and degree of conversion of posterior packable composites. Oper Dent. 2004;29(6):642-9.

22. Ersoy M, Civelek A, L'Hotelier E, Say EC, Soyman M. Physical properties of different composites. Dent Mater J. 2004;23(3):278-83. 